\title{
PENGGUNAAN MEBEL TAMIA DALAM PEMBELAJARAN MENULIS TEKS DESKRIPSI BANGUNAN BERSEJARAH KOTA PASURUAN
}

\author{
Fika Rahmawati \\ SMP Negeri 7 Kota Pasuruan
}

INFO ARTIKEL

Diterima:5-02-2020

Disetujui:7-02-2020

Kata Kunci:

mebel tamia, menulis, teks deskripsi

\begin{abstract}
Abstrak: Pembelajaran abad 21 ditandai dengan media digital yang digunakan dalam proses pembelajarannya atau seringkali disebut revolusi industri 4.0. Penggunaan media digital pada abad 21 ini bukan berarti jika media konvensional tidak bagus atau layak digunakan dalam pembelajaran. Saat guru dapat memanfaatkan media tersebut secara maksimal, media kovensional juga dapat membawa nilai positif tersendiri pada peserta didik. Seperti halnya pembelajaran menulis teks deskripsi. Proses pembelajaran materi ini dapat menggunakan media konvensional seperti Mebel Tamia. Mebel Tamia singkatan dari Media Belajar Taman Miniatur dapat membantu siswa dalam proses pembelajaran menulis teks deskripsi berupa objek bangunan bersejarah Kota Pasuruan.
\end{abstract}

\begin{abstract}
: 21st century learning is characterized by digital media used in the learning process or often called the industrial revolution 4.0. The use of digital media in the 21 st century does not mean that conventional media is not good or suitable for use in learning. When teachers can make the most of these media, conventional media can also bring their own positive values to students. Like learning to write description text. The learning process of this material can use conventional media such as Tamia Furniture. Furniture Tamia stands for Taman Learning Miniature Media can help students in the learning process of writing description texts in the form of historical buildings in Pasuruan City.
\end{abstract}

Alamat Korespondensi:

Fika Rahmawati

SMP Negeri 7 Kota Pasuruan

e-mail: lefi.figo24@gmail.com

Pembelajaran pada abad ke-21 menuntut beberapa keterampilan yang harus dilatihkan kepada siswa. Hal ini berkaitan dengan era globalisasi yang terus mengalami perubahan. Siswa dihadapkan dengan tantangan global yang luar biasa kerasnya. Oleh karena itu, untuk mampu bertahan dan tangguh dibutuhkan keterampilan hidup yang sesuai dengan perkembangan zaman. Dalam Partnership for $21^{\text {st }}$ Century Skills (2015) dijelaskan bahwa ada empat keterampilan hidup pada abad ke-21, yaitu kreativitas dan inovasi, berpikir kritis dan memecahkan masalah, komunikasi, dan kolaborasi. Pembelajaran abad 21 ditandai dengan media digital yang digunakan dalam proses pembelajarannya atau seringkali disebut revolusi industri 4.0.

Penggunaan media digital pada abad 21 ini bukan berarti jika media konvensional tidak bagus atau layak digunakan dalam pembelajaran. Saat guru 
dapat memanfaatkan media tersebut secara maksimal, media kovensional juga dapat membawa nilai positif tersendiri pada peserta didik. Media konvensional menjadi berharga jika guru dapat meramunya menjadi media yang multifungsi dan bermanfaat dalam proses pembelajaran. Media konvensional juga dapat membuat peserta didik berpikir kritis, kreatif, dan berinovasi.

Materi pembelajaran akan lebih mudah dan jelas jika dalam pembelajaran menggunakan media pembelajaran. Hal tersebut sejalan dengan pendapat Musfiqon (2012:28) yang menyatakan bahwa media pembelajaran adalah alat bantu yang berfungsi untuk menjelaskan sebagian dari keseluruhan program pembelajaran yang sulit dijelaskan secara verbal. Adapun tujuan media pembelajaran sebagai alat bantu pembelajaran, yaitu mempermudah proses pembelajaran di kelas, meningkatkan efisiensi proses pembelajaran, menjaga relevansi antara materi pembelajaran dengan tujuan belajar, dan membantu konsentrasi pembelajaran dalam proses pembelajaran. Manfaat media pembelajaran sebagai alat bantu dalam proses pembelajaran, yaitu pengajaran lebih menarik perhatian pembelajar, bahan pengajaran akan lebih jelas maknanya, metode pembelajaran bervariasi, dan pembelajar lebih banyak melakukan kegiatan belajar.

Mebel Tamia adalah salah satu media pembelajaran yang dapat membantu guru dalam proses pembelajaran. Mebel Tamia singkatan dari Media Belajar Taman Miniatur ini adalah media belajar tiga dimensi yang dibuat secara permanen sehingga dapat digunakan dalam jangka waktu yang lama (minimal tiga tahun). Media ini terdapat di lingkungan SMP Negeri 7 Kota Pasuruan sebagai salah satu media yang dimanfaatkan guru dalam proses pembelajaran.

Media Belajar Taman Miniatur ini dapat digunakan oleh beberapa mata pelajaran, khususnya pelajaran bahasa Indoesia. Kompetensi dasar yang dapat memanfaatkan media ini salah satunya adalah menulis teks deskripsi. Teks deskripsi adalah jenis teks yang menggambarkan objek secara detail seolah-olah pembaca ikut merasakan atau melihat objek tersebut. Hal ini sesuai dengan pendapat Dalman (2009: 13) yang berpendapat bahwa deskripsi adalah ragam wacana yang melukiskan atau menggambarkan sesuatu berdasarkan kesan-kesan dari pengamatan, pengalaman, dan perasaan penulisnya. Sasarannya adalah menciptakan atau memungkinkan terciptanya daya khayal atau imajinasi pembaca sehingga dia seolah-olah melihat, mengalami, dan merasakan sendiri apa yang dialami penulisnya.

Berdasarkan latar belakang di atas, penelitian ini berupa gambaran penggunaan Mebel Tamia dalam pembelajaran menulis teks deskripsi bangunan bersejarah Kota Pasuruan.

\section{METODE}

Penelitian ini menggunakan metode kualitatif deskriptif, bertujuan untuk mendeskripsikan secara terperinci tentang Pemanfaatan Mebel Tamia dalam pembelajaran mendeskripsikan bangunan bersejarah Kota Pasuruan. Dalam penelitian kualitatif, data yang digunakan berupa data-data deskriptif berupa katakata tertulis yang digunakan untuk meneliti pada kondisi objek alamiah, di mana peneliti sebagai instrumen kunci. Teknik pengumpulan data dilakukan dengan cara wawancara secara mendalam terhadap siswa dan guru kelas yang mengajar di SMP Negeri 7 Pasuruan. Analisis data yang diguankan peneliti menggunakan model Miles dan Hubberman yang terdiri dari tiga langkah, yaitu reduksi data, penyajian data, dan penarikan kesimpulan (Sugiyono, 2015: 334). 
KARANGAN: Jurnal Kependidikan, Pembelajaran, dan Pengembangan, Vol 02, No 01, Bln Feb, Tahun 2020, Hal 15 - 20

\section{HASIL}

\section{A. Pengertian Mebel Tamia}

Media Belajar Taman Miniatur atau disingkat dengan Mebel Tamia ini dibuat dari bahan bangunan yang dibentuk menyerupai bentuk bangunan aslinya. Pembuatan media ini diharapkan mampu menumbuhkan motivasi dan antusias siswa dalam proses pembelajaran sehingga dapat meningkatkan hasil pembelajaran.

Proses pembelajaran yang dilaksanakan tak luput dari perangkat pembelajaran yang sudah disiapkan guru. Oleh karena itu, perangkat pembelajaran yang dibuat harus terdapat media pembelajaran kreatif yang dapat mempermudah siswa dalam memahami materi. Salah satu media yang dapat digunakan dalam perangkat pembelajaran tersebut adalah Mebel Tamia. Adapun taman miniatur yang dapat dijadikan sebagai media belajar di SMP Negeri 7 Kota Pasuruan sebagai berikut.

1) Taman Pusaka, yaitu taman yang berisi miniatur bangunan-bangunan bersejarah yang ada di Kota Pasuruan. Taman ini mencoba mengenalkan bangunan-bangunan bersejarah Kota Pasuruan yang wajib diketahui oleh siswa. Miniatur tersebut antara lain: miniatur Gedung 8, miniatur Alun-Alun Kota Pasuruan, miniatur Rumah Singa, miniatur Mebel. Taman ini dapat dimanfaatkan untuk pembelajaran bahasa Indonesia, bahasa Inggris, IPS, PKn, Bahasa Daerah, Seni Budaya, BK, dan Matematika.

1) Taman Budaya, yaitu taman yang berisi miniatur rumah adat. Rumah adat tersebut antara lain: rumah adat suku Asmat, rumah adat suku Jawa, rumah adat Minangkabau, dan rumah adat Toraja. Taman ini dapat dimanfaatkan untuk pembelajaran bahasa Indonesia, bahasa Inggris, IPS, PKn, Bahasa Daerah, Seni Budaya, BK, dan Matematika.

2) Taman Religi, yaitu taman yang berisi miniatur tempat peribadatan agamaagama yang ada di Indonesia. Miniatur tempat peribadatan yang ada yaitu: miniatur Gereja untuk tempat ibadah Agama Kristen, miniatur Pura untuk tempat ibadah Agama Hindu, miniatur Vihara untuk tempat ibadah Agama Budha, dan miniatur Klenteng untuk tempat ibadah agama Konghuchu. Miniatur gereja dan klenteng juga teramsuk bangunan bersejarah Kota Pasuruan yang harus diketahui oleh siswa. Tempat ibadah untuk agama Islam tidak dibuatkan miniaturnya, karena sudah terdapat Mushollah sekolah yang setiap hari digunakan untuk kegiatan keagamaan siswa SMP Negeri 7 Kota Pasuruan. Taman ini dapat dimanfaatkan untuk pembelajaran bahasa Indonesia, bahasa Inggris, IPS, PKn, Bahasa Daerah, BK, Pendidikan Agama, dan Matematika.

3) Taman Matematika, yaitu taman yang berisi miniatur bangun datar yang sekaligus berfungsi sebagai kursi taman. Miniatur bangun datar ini memudahkan siswa dalam mengamati dan menghitung langsung objeknya atau bangun datarnya.

4) Taman Satwa, yaitu taman yang berisi miniatur binatang-binatang yang dapat dijadikan sebagai media pembelajaran. Taman ini dapat dijadikan media untuk mata pelajaran IPA, yaitu materi keanekaragaman hayati dan ekosistem. Mata pelajaran IPS dapat memanfaatkan taman ini untuk materi flora dan fauna. Mata pelajaran bahasa dapat memanfaatkannya untuk materi deskripsi, narasi, dan lain sebagainya.

Dari beberapa taman miniatur yang ada, pembelajaran menulis teks deskripsi lebih menggunakan Taman Pusaka sebagai medianya. Bangunan bersejarah Kota Pasuruan lebih terlihat dapat dideskripsikan dengan baik. Hasil tulisan deskripsinya nanti akan dapat dijadikan sebagai wawasan bagi siswa tentang bangunan bersejarah yang dimiliki kota Pasuruan. 


\section{B. Langkah-langkah Pembelajaran}

Pembelajaran menulis teks deskripsi dengan menggunakan Mebel Tamia di

SMP Negeri 7 dilakukan dengan langkah-langkah sebagai berikut.

1. Peserta didik membentuk kelompok. Pembentukan anggota kelompok berdasarkan bagunan bersejarah Kota Pasuruan yang disebutkan.

2. Tiap kelompok mendapatkan satu gambar bangunan bersejarah sebagai stimulan dalam menentukan identifikasi atau gambaran umum.

3. Peserta didik secara berkelompok menyusun idnetifikasi atau gambaran umum dari gambar yang didapatkannya. Gambar berupa bangunan sejarah Kota

Pasuruan.

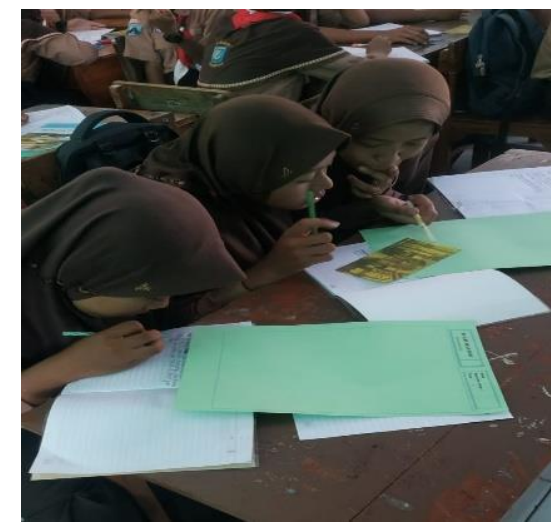

Gambar 1 Aktifitas siswa saat menentukan bagian identifikasi

4. Setelah mampu menentukan gambaran umum objek bangunan bersejarah, peserta didik langsung mengamati miniatur bangunan bersejarah sesuai dengan gambar yang dimiliki kelompok.

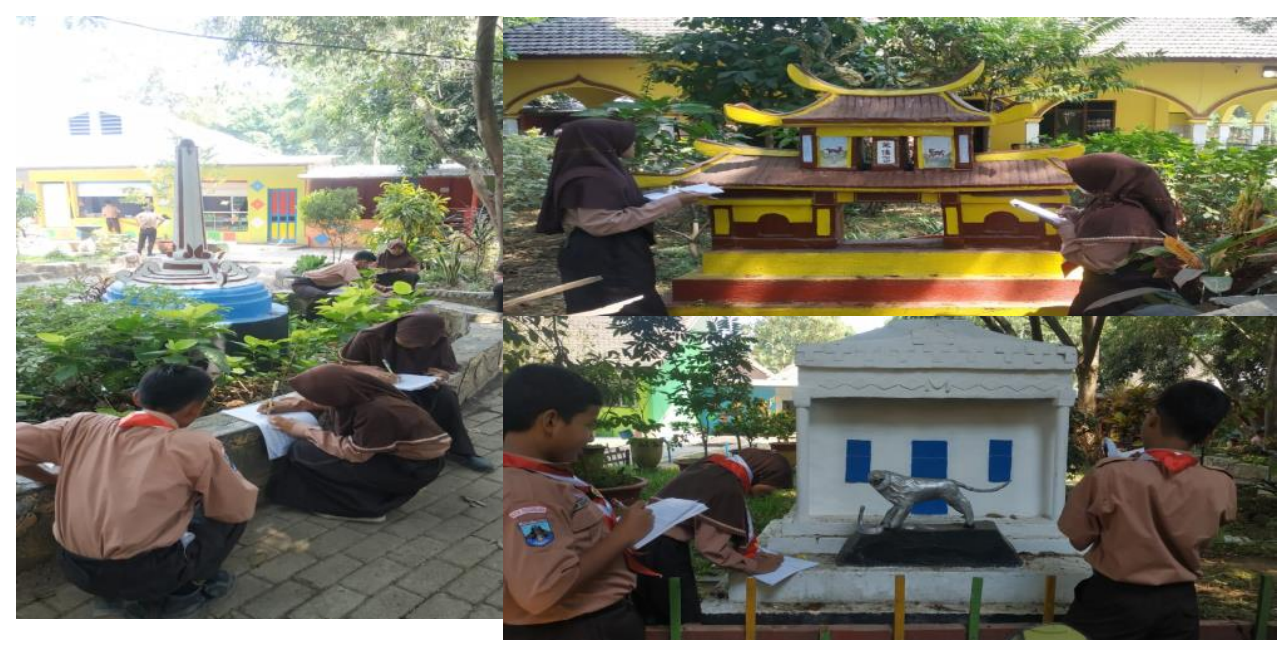

Gambar 2 Aktifitas siswa saat menggunakan Mebel Tamia

5. Peserta didik mendeskripikan bagian dari bangunan sejarah tersebut secara detail dan mendalam.

6. Peserta didik kembali ke dalam kelas untuk menyusun bagian simpulan atau kesan. 
KARANGAN: Jurnal Kependidikan, Pembelajaran, dan Pengembangan, Vol 02, No 01, Bln Feb, Tahun 2020, Hal 15 - 20

\section{Hasil Yang Dicapai}

Dari hasil kegiatan mendeskripsikan bangunan bersejarah dengan menggunakan Mebel Tamia tersebut, ada beberapa hasil yang dicapai sebagai berikut.

1. Terwujudnya proses pembelajaran yang lebih bermakna dan berkesan sehingga dapat membangkitkan motivasi dan minat belajar peserta didik lebih baik

Proses pembelajaran menjadi lebih bermakna karena peserta didik mengamati secara langsung objeknya. Pemahaman peserta didik terhadap materi menjadi lebih baik. Objek yang berbeda juga menjadi motivasi sendiri bagi peserta didik dalam mendeskripsikannya secara terperinci. Motivasi ini dapat meumbuhkan minat belajar peserta didik dalam pembelajaran, khususnya pelajaran Bahasa Indonesia.

2. Peserta didik menjadi lebih aktif dalam proses pembelajaran

Proses pembelajaran di luar kelas dengan kegiatan mengamati suatu objek menjadikan peserta didik menjadi lebih aktif. Hal ini dapat terlihat saat peserta didik benar-benar menghitung jumlah tiang bangunan atau sekedar bertanya tentang bagian bangunan yang sedang diamatinya. Hampir seluruh peserta didik aktif dalam proses pembelajaran di luar kelas tersebut.

3. Tingginya motivasi dan minat belajar sehingga mampu membawa pengaruh psikologis yang baik terhadap peserta didik

Tingginya motivasi dan minat belajar peserta didik dalam pembelajaran mendeskripsikan bangunan bersejarah dengan menggunakan Mebel Tamia secara tidak langsung membawa pengaruh psikologis yang baik terhadap peserta didik. Peserta didik dapat saling tukar pendapat dengan kelompoknya tentang apa saja yang dilihatnya selama proses pengamatan berlangsung. Peserta didik juga berani bertanya kepada guru tentang objek yang diamati.

4. Hasil menulis teks dekripsi di atas nilai KKM (Kriteria Ketuntasan Mengajar)

Keantusiasan peserta didik dalam pembelajaran mendeskripsikan bangunan bersejarah dengan menggunakan Mebel Tamia berdampak positif pada hasil menulisnya. Nilai yang diperoleh oleh seluruh peserta didik dalam pembelajaran menulis teks deskripsi ini di atas KKM. Padahal, jika dilihat dari hasil menulis siswa jika tidak menggunakan media seperti ini dengan materi selain teks deskripsi seringkali masih ditemukan nilai di bawah KKM. Oleh karena itu, jika nilai seluruh peserta didik dalam pembelajaran menulis teks deskripsi di atas KKM menunjukkan jika media Mebel Tamia layak dan bagus digunakan dalam proses pembelajaran.

\section{SIMPULAN}

Berdasarkan pembahasan pada subbab sebelumnya, maka dapat disimpulkan bahwa penggunaan Mebel Tamia layak dan bagus digunakan dalam proses pembelajaran, khususnya materi teks deskripsi dengan kompetensi dasar menulis teks deskripsi. Beberapa hasil yang dapat dicapai dalam penggunaan media ini adalah (1) terwujudnya proses pembelajaran yang lebih bermakna dan berkesan sehingga dapat membangkitkan motivasi dan minat belajar peserta didik lebih baik, (2) peserta didik menjadi lebih aktif dalam proses pembelajaran, (3) tingginya motivasi dan minat belajar sehingga mampu membawa pengaruh psikologis yang baik terhadap peserta didik, dan (4) hasil menulis teks dekripsi di atas nilai KKM (Kriteria Ketuntasan Mengajar). 


\section{DAFTAR RUJUKAN}

Dalman. 2013. Menulis Karya Ilmiah. Jakarta: PT. Radja Grafindo Persada.

Musfiqon. 2012. Pengembangan Media dan Sumber Pembelajaran. Jakarta: Prestasi Pustaka Raya

P21. 2015. P21 Framework Definitions, (Online),

(http://www.p21.org/storage/documents/docs/P21 Framework Definition New Logo-2015.pdf), diakses pada 15 September 2019.

Sugiyono. 2015. Metode Penelitian Kombinasi (Mixed Methods) Cetakan Ketujuh. Bandung: Alfabeta. 